\title{
I: Languages of Nature, Culture, and Civilization: LETTERS OF A TRAVELER
}

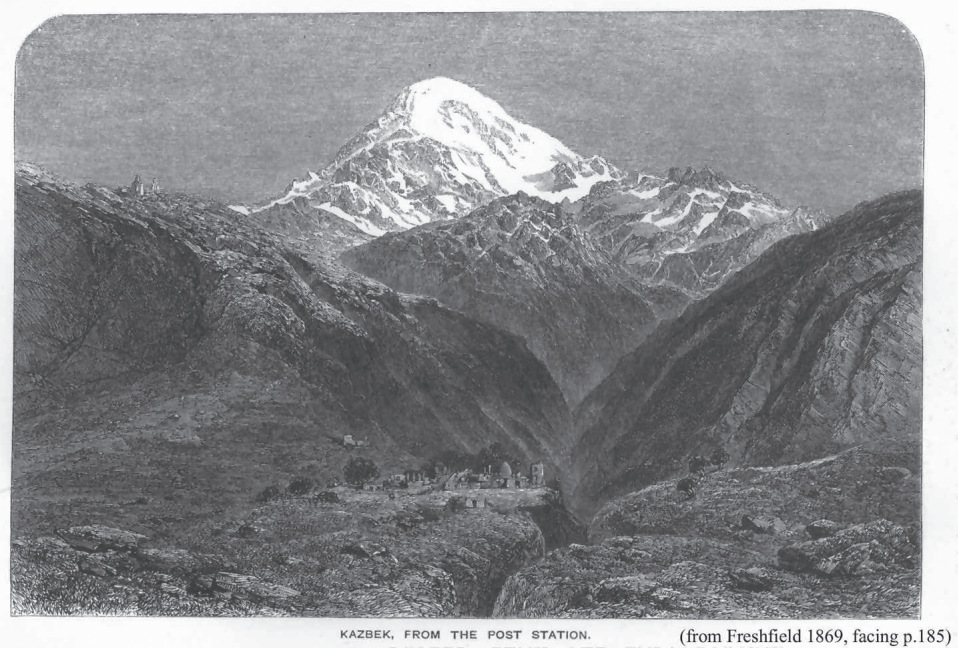

Figure 2

The situation of the post station (at Kazbek) has no beauty except when the great mountain is unveiled. Then the picture seen from the windows will not easily be forgotten. Again and again, it has been painted and photographed; it is met with in every book of travel, even in the shop windows of St. Petersburg. It is the keepsake view-the Jungfrau from Interlaken—of the Caucasus. (Freshfield 1896, 87)

The Dariel pass through the Caucasus today, as in the nineteenth century, provides the main viable route between Russia and Georgia, the Georgian military road. The journey from Vladikavkaz in modern North Ossetia into Georgia follows the Terek River, which flows north from Mount Kazbek (Georgian Qaz[i]begi, also Mqinvari "glacier") into Russia, while the southern flanks of the route follow the Aragvi River, flowing south toward Tbilisi (see map 1). This journey from Vladikavkaz to Tbilisi and vice versa is across some very well-traveled literary terrain for European, Russian, and Georgian Romantics (see for example Greenleaf 1991, 1994; Layton 1994, Ram and Shatirishvili 2004, Manning 2008), whose overlapping narratives in genres from fairy tale to travel account, 
lyric verse to adventure tale, gave the landscape a peculiar ambivalence where fact and fancy were intertwined, so much so that the Dariel gorge itself has sometimes been called "a fairy tale in twelve versts" (Graham $1911,164)$. It is in this rugged and well-traversed piece of literary and geographical terrain that the noted Georgian writer Ilia Chavchavadze (1837-1907) positioned his travelogue-cum-literary manifesto, Letters of a Traveler (Mgzavris Cerilebi [composition begun in 1861, first published in 1871, and again in a fuller uncensored version in 1892]). ${ }^{1}$

Chavchavadze's Letters of a Traveler is perhaps the single most important piece of political writing of the Georgian generation of the 1860s, who called themselves Terg-daleulebi ("those who have drunk from the Terek River"). This term has potentially ambiguous reference in this text, denoting at once a member of the Russian-educated Georgian gentry intelligentsia represented by the narrator, who is Terg-daleuli because he has crossed ("drunk from") the Terek, the boundary between Russia and Georgia, in search of enlightenment, as well as denoting a member of the Georgian people, Lelt Ghunia, who as a Moxevian peasant, dwells beside the Terek River in Xevi, and could therefore implicitly be taken as a true Terg-daleuli. ${ }^{2}$ The term Terg-daleuli itself undergoes a transformation and revalorization in the course of the text from the first sense to the second, as Chavchavadze becomes disenchanted with the promises of Russian civilization and discovers authentic culture instead among the Georgian folk. This transition is mirrored in the natural order in the changes in the character of the Terek River itself from the placid, servile Terek in the Russian plains at Vladikavkaz to the torrential, free Terek in the Caucasus mountains.

In this chapter, I am primarily interested in exploring the rhetorical opposition between form and content of Lelt Ghunia's speech, whose correct realistic representation Chavchavadze presents, in his coda, as being the only project of the text. I argue that Chavchavadze uses this opposition both to naturalize his own relationship to the peasant Lelt Ghunia as a member of the "intelligentsia" to the "people," creating an organic unity of language, a nation. At the same time, the lack of relationship between form and content in the disjointed dialogue of a drunken Russian officer he meets along the way has the opposite effect, emphasizing the immense gap between the pretenses of Russian civilization (form) and its actual effects in the lives of the Georgian people (content). In this manner, as the partner in two very different dialogues, Chavchavadze 
implicitly inserts himself between the Russian colonizing state and the colonized Georgian people as a mediating figure, as a Terg-daleuli in both the above senses, educated in Russia, Chavchavadze yet remains a Georgian, able to speak both languages and thus to bridge the gap between Russian civilization and Georgian folk culture.

It may seem odd that a Georgian movement for political and cultural reform would take its name (Terg-daleuli) from a river in the Caucasus mountains on the very border of Georgia (the Terek, Georgian Tergi), but here too Chavchavadze was locating himself in relation to an existing "geopoetic" tradition in which the political order was construed in terms of the natural order. In their discussion of the poetry of an earlier generation of Georgian Romanticism, Ram and Shatirishvili (2004) argue that Georgian gentry poets of an earlier generation used different "geopoetic" strategies to reduce the triadic opposition between Russia, Georgia, and the Caucasus into a dualist opposition expressive of their newfound and ambivalent position as a relatively privileged colonial class under Russian rule. A central tendency of such "geopoetics" is to elide the opposition between Russia and Georgia over and against the warlike and uncivilized tribes of the Caucasus (on which imaginings, see Layton 1997). In the text examined here however, Ilia Chavchavadze creates a defiant prose manifesto aimed at this earlier generation's geopoetics and geopolitics and proposes a new geopoetic strategy, eliding the opposition between Georgia and the Caucasus over and against Russian domination. ${ }^{3}$ He does so first of all by appropriating the wellknown image of the Terek River as a multivalent symbol of Caucasian freedom and savagery (Layton 1994), translating its untamed roar into a human voice expressing the woes of his motherland (thereby identifying the Caucasus with Georgia). Second, moving from nature to culture, he finds his exemplary Georgian speaker from among the territorially most marginal speakers of Georgian, the Moxevians, who dwell by the Terek in the Caucasus between Russia and Georgia. It is in their appropriated voice and dialect that the political ideology of Terg-daleuli gentry nationalism is delivered by proxy. Terg-daleuli mountaineer dialect paradoxically becomes the vehicle for Terg-daleuli gentry ideology.

In this respect, the text to be discussed here represents a radical change in the role of language and especially folk language as having an increasingly constitutive role in the imagining of larger social totalities, such as "nations" and "peoples," a change experienced both in Georgia and more 
generally throughout Europe in the nineteenth century. In this century, language increasingly came to be seen as a uniquely natural sign of social membership; hence a common linguistic heritage-however dialectically stratified-could suture together enlightened society and the unenlightened people. In contrast to older elites, in Georgia as elsewhere, these new elites increasingly resorted to language-based forms of legitimacy of social projects, seeing in these a kind of "authority of authenticity" (Gal and Woolard 2001). Like the texts of an earlier generation of Georgian Romantics (Ram and Shatirishvili 2004), this text places Georgia and the elites who spoke for it in a "geopoetic" context in which the crucial terms to which it is to be related are the Caucasus and Russia. Giving his reading of the aesthetics of this literary landscape, Chavchavadze engages his Romantic literary forebears in an explicitly political dialogue and offers a radical revision of the imaginative geography that separates Georgia from the Caucasus. Unlike these texts, however, in which intertextual relations are primarily with Russian antecedents, Ilia Chavchavadze engages both Georgian and Russian literary antecedents, as well as the voice of the "people" of whose voice Chavchavadze is the mere transcriber. Whereas travel accounts through the Caucasus by Romantics, Georgian and otherwise, represent it as a moving, but silent, landscape, Chavchavadze populates this landscape, positing a close, almost organic connection between the voice of nature in the form of the Terek River and the voice of the people in the form of Lelt Ghunia, a peasant dwelling by the Terek, thus at once humanizing the indigenous natural order (the Terek) and naturalizing the human order (Lelt Ghunia).

\section{Author, Text, Context}

Before addressing the main issue of this chapter-language as the basis for a national protest against Russian imperial civilization-a brief introduction of Ilia Chavchavadze, perhaps the most prominent and significant member of the generation of the 1860s, the Terg-dauleulebi, in Georgia, is in order. His multiple activities as writer, publicist, editor, and cultural reformer were instrumental in the development of Georgian print culture and the formulation of the ideological position of what may be called "gentry nationalism" (the term is Suny's [1988, 133-134]) in the late nineteenth century. His assassination in 1907 by parties unknown provided this group with a martyr, bringing this somewhat 
marginal nationalist ideology into closer alignment with more popular movements for social justice, thus helping to transform and combine the social and national movements in Georgia in the wake of the disappointment of failure of the "social movement" in Georgia during the 1905 revolution. ${ }^{4}$ Known to Georgians simply as "Ilia," Chavchavadze was made an Orthodox saint in the last years of Soviet power, and to this day he remains the central authoritative figure for Georgian nationalism. Chavchavadze was also a key figure in articulating the relations between older nobility and the emergent intelligentsia in Georgia, for he belonged to both classes. A noble by birth, he attended university in the Faculty of Law in St. Petersburg from 1857 to 1861 and returned a member of the nascent Georgian intelligentsia, that is, as a true terg-daleuli, in the sense of one who crossed the Terek (the boundary of Russia and Georgia) to receive an education (on this sense of the term, see Suny 1988). Writing at a time when a Georgian print culture and a class of intelligentsia were emerging from the manuscript culture and court sociability of the nobility, he straddled both spheres as noble and writer of poetic manuscripts and printed prose. He engaged in debates with representatives of the older generation of the nobility like Grigol Orbeliani (1804-1883) on the proper form of literary Georgian, arguing for a style closer to that of the spoken norms of the folk (see below, chapter 4). Typical of the changes and contradictions of the period, these debates concerning the modernization and popularization of a Georgian print language and print culture were conducted in a typically classical and aristocratic form-a series of traditional exchanges of poetry in traditional meters, disseminated "domestically" by mouth or manuscript among members of the Georgian urban gentry, and only later publicized in print. The text, Letters of a Traveler, shares many of these ambiguities, since it circulated in various manuscript forms through aristocratic urban networks, encountering a face-to-face public over a period of ten years; it was eventually published for a potentially popular readership of anonymous contemporaries in full, uncensored and authoritative form thirty years later in 1892 .

The text also witnesses other transformations as the Georgian aristocracy transformed itself into a Georgian intelligentsia. Just as the generation-defining poetic debate on literary style between Orbeliani and Chavchavadze revolved around the choice between an adherence to classicism (Orbeliani) and the need for a language that was popular, folk (Chavchavadze), so too we see in this text the first systematic attention 
to the description of a folk dialect in Georgian, the first application of the narodnik principles that were in the air in Russia (Chavchavadze had met the well-known Russian reformer Chernyshevsky in Russia) and now were applied to Georgia (with an extremely heavy admixture of apologetics for the preexisting feudal order, it should be noted, hence "gentry nationalism"). More generally, it was the first Georgian evidence of the trans-European turn to popular language-based forms of legitimation for elites. This turn to the people or folk (xalxi), of course, occurs on the eve of the Emancipation of the serfs in Georgia, and a transformation in the role of the Georgian nobility. Originally a rural agrarian estate depending on the serfs, the Georgian elite would become urban-educated class of bureaucrats, court officials, writers, and nascent intelligenty who in different ways would constitute themselves rhetorically as being in the service of "the people," in whose voice, and therefore, in whose language, they spoke. As a result, in this text, more than in any other of the period, the question of linguistic form takes on immediately political content.

\section{Synopsis of the Text}

Chavchavadze's Letters of a Traveler is a fairly short text divided into eight passages, narrating his journey from Vladikavkaz in modernday Ossetia into Georgia across the Dariel pass. In the first section (I), which was heavily censored in the first printing of 1871, we encounter Chavchavadze in Vladikavkaz, taking leave of his traveling companion, a Frenchman. This authentic representative of Europe appears seemingly only to marvel at the backwardness of the Russian (postal) transportation system before he goes on his way. With a sideward glance at Russian artists' idealization of their own folk ("The reality is twice as repulsive as their pictures are beautiful"), he gives us an unflattering and detailed description of a Russian post cart driver (yamshchik), who is presented as being coarse, ugly, and stupid.

In the second passage (II), Chavchavadze leaves Vladikavkaz, and from this point the Terek River becomes his constant traveling companion. As he crosses a bridge over the Terek, he notes that it no longer resembles the madly rushing, "heroic-demonic Terek" found in the Caucasus and celebrated by Orbeliani, whose poem "Saghamo Gamosalmebisa" "Night of Farewell" [1959 (1841), 58-9]) he cites twice in this passage. In the 
first of a series of allegorical meditations on the Terek, Chavchavadze identifies this change in the nature of the Terek from mountains to plains explicitly with both with the passivity of the Russian peasantry and cooptation of the Georgian gentry under Russian rule: "That destructive Terek! How two-faced it has been! See how deathly it is. Whenever it turns its back to us and its face to Russia, when it gets into the plains and the flat country, somehow that demonic, heroic voice ceases.... There it is as placid, as silent, as if it dwelt under the rod or had received a high official post." At the end of the section, he has reached the post station at Lars, where he reflects on the value of his four years of education in Petersburg, from which he is returning.

In the third section (III), Chavchavadze's random and confused reflections on what he has seen, suffered, and learned at home and abroad undergo what he describes as a "revolution," and he wonders whether these same four years away from his native land will make him a stranger to his land, unable to speak or understand its language and its complaints. His reverie is interrupted by a drunken Russian officer, who engages him in an unintentional mockery of enlightened discourse, first as an equal based on the fact that Chavchavadze is an emissary from civilization (Petersburg), and then when he finds that Chavchavadze is actually a Georgian, as a subaltern Oriental "local" in need of enlightenment. In the deranged conversation that ensues, Russia's pretenses to a civilizing mission are further deflated, as the drunken officer proves unable to define the terminology of civilization except in the most vulgar and debased terms.

The next two sections (IV-V) occur at the post station of Stepantsminda (also known as Kazbek), the first Georgian village along the route. Chavchavadze polemically engages with Orbeliani once more (IV) at sunset at Kazbek post station, citing another of Orbeliani's poems (Sadghegrdzelo "Toast" (1959 [1827-1870]), and covertly alluding to the description of nature contained in Orbeliani's "Night of Farewell," which takes place at the same spot. Here Chavchavadze makes another series of polemical, allegorical ruminations, this time on the opposition between Mount Kazbek and the rushing Terek River at its feet; he repudiates the gleaming inaccessibility of the mountain for the muddy raging torrents of the Terek, the former identified with idealism, death, and stasis, the latter identified with materialism, life, and above all, motion and circulation. At nightfall in section V, Chavchavadze has an epiphany with the 
Terek River at its center-an epiphany which causes him to understand and identify with its voice. Here again, he allegorizes the silence and darkness of night as ignorance and lack of enlightenment, while the "unsilenced complaint" of the Terek in the darkness embodies human life awakened to the promise of a new day.

Departing Kazbek at dawn the next day, Ilia then has two conversations with Lelt Ghunia (VI-VII), who as a local mountaineer "Terekdrinker" peasant stands both in physical and mental counterpoint to the Russian post cart driver at Vladikavkaz: "In the end it appeared that he was an interested observer of that little land which fate had outlined around him and which she had appointed to vary his colorless life" (VI). Lelt Ghunia further clarifies the destruction actually wrought by Russian colonization in counterpoint to its putative civilizing mission presented in the dialogue at Lars (III), particularly dwelling on the corrosive effects of Russian rule on the (allegedly) once harmonious relations within and between estates. He concludes,

This I want you to understand, that formerly if we gave our lives in service there were rewards, there were great gifts; we found our livelihood in glory and in bravery, a man did not live in vain. Now we find our livelihood in lying, immorality, breaking oaths, and in betraying one another. (VII)

Lastly, in the coda of the text (VIII), Chavchavadze explains that his sole purpose has been to dutifully record the ethnographic text found in the two preceding sections realistically. That is, his focus has been only on realistic verisimilitude to the form and not the factual veracity of Ghunia's speech:

Whether my Moxevian spoke the truth or not I will not now inquire. And what business is it of mine? I merely mention in passing what I as a traveler heard from him. My one endeavor in this has been to give to his thoughts their own form and to his words his accent. If I have succeeded in this I have fulfilled my intention. (VIII)

For the remainder of this chapter, I will use roman numeral section 
headings (I-VIII) uniquely to identify passages from Ilia's text, whose relative location in the Dariel pass is indicated on the map (see map).

\section{The Voice of the Intelligentsia and the Voice of the People}

Chavchavadze presents Letters of a Traveler as a simple exercise in representational "realism," an absolutely neutral transcription of an ethnographic and linguistic reality, characteristic of the generation of the 1860s. Part of the central importance of the text then, is that it represents an important first systematic attempt at the faithful description of the dialect and political institutions of the Georgian "people."5 This serious attention to correct representation of dialect form and ethnographic content is surely motivated by a new literary taste for "realism" (Paperno 1988). However, Chavchavadze's realism was strongly influenced by Russian understandings of realism as a kind of "civic aesthetics" (affirming the social role of literature) exemplified by writers like Chernyshevsky and shows a similar appreciation of the critical potential afforded by the aesthetic (Paperno 1988, 7). Also, like Chernyshevsky's realism, Chavchavadze's realism (like most other Russian and Georgian writers in the period) is a "social realism," an aesthetic of realism strongly tied to the "social question," describing the abject condition of the peasants in the Emancipation period (Frierson 1993). As with Russian social realism, the apparently neutral aesthetic perspective of realistic description becomes a rhetorical device allowing Chavchavadze to covertly critique the Russian colonial state, the obscurantism of whose civilizing pretenses is represented by a systematic failure of the forms of words to match their content. At the same time, while the form of Lelt Ghunia's transcribed conversation is humble terg-daleuli (Moxevian) dialect, the content of Lelt Ghunia's conversation is in effect the political program of the terg-daleuli intelligentsia. Hence, the opposition between form and content thematically central to the text becomes an organizing rhetorical opposition.

Presenting his work as an anonymous traveler's simple act of transcription of the voice of Lelt Ghunia, Chavchavadze makes his text pivot around this central identification - an elision which creates the "authority of authenticity" (Gal and Woolard 2001, 7) by which Chavchavadze identifies his own voice with the authentic voice of the terg-daleuli peasant, Lelt Ghunia. The text was composed in the 1860s (from 1861 to 1871) at the same time as the term intelligentsia was beginning to be 
used in Russian (and Georgian) society (Confino 1972, 117, Burbank 1996, 97). Not surprisingly, then, it replicates all the ambiguities which characterized the position of the imperial intelligentsia during the Great Reforms of the 1860s. This relation is made more complex, moreover, by Chavchavadze's position as a member of a colonized intelligentsia whose position reflects the peculiarities of the specificities of Georgian gentry intelligentsia under Russian colonialism. ${ }^{6}$ As an intelligentsia manifesto, the text replicates the very "gulf between society and the people" that it seeks to mediate-that between a small educated reading public, mostly composed of gentry (the Georgian term sazogadoeba can mean aristocratic "society" or intelligentsia "public," compare Russian obshchestvo) and an often illiterate people, mostly composed of peasantry (Georgian xalxi, Russian narod) (Brooks 1978, 98, Todd 1986, 15ff; Gleason 1991, Frierson 1993). This "society" of the "fathers" gave birth to a (still mostly gentry) "intelligentsia" of the "sons" in the 1860s in fierce intergenerational debates that characterized "the reality of intelligentsia culture-an ongoing, hence self-contested, and selfrefining culture based on personal and public statements about politics" (Burbank 1996, 107). As this intelligentsia culture was founded on opposition to autocracy and a notion of service to the "people," however imagined (Confino 1972, Gleason 1991, 20-1, Burbank 1996), so this text also opposes the discourses of the Russian colonizing state to those of the colonized Georgian people, using the ethnographic descriptions of the defunct political institutions of Georgian folk culture to critique the civilizing pretenses of the Russian state.

The dialogism of the text replicates all these well-known antinomies. In fact, the peculiarity of the text is the distinct form of the intertextual and intratextual strategies (Jenny 1976, 260; Bauman 2004) that Chavchavadze uses to mediate them, as well as the distinct strategic functions of these forms. An intertextual dialogue involving both overt citation and covert structural imitation or prior Russian and Georgian Romantic texts addresses the text to a purely literary public of Georgian intelligentsia. Rather than address these forebears directly, he addresses them indirectly through his own aesthetic discussion of the "already spoken about" landscape, largely through a radical rereading of the "voice" of the Terek River itself.

His radical rereadings of the natural landscape produces a literary filiation (Hubbard 1998), which locates this text within a retroactively 
imagined "intelligentsia tradition" (Confino 1972, Burbank 1996), thus performatively creating a literary genealogy for the text. Because Chavchavadze is a member of a colonial intelligentsia, this literary kinship is reckoned bilaterally, with both Russian and Georgian Romantic antecedents. At the same time, the text reports an actual dialogue with the actually existing folk who are not, it should be remembered, part of the audience of the text. The "people" are not yet a "public" (Gleason 1991). ${ }^{7}$ Juxtaposition of the differing dialects of intelligentsia and folk in dialogue reveals the essential linguistic relatedness of intelligentsia and folk, their fraternal membership in a speech (if not literary) community of "Georgians." If the intertextual relationship creates vertical, generational, intertextual kinship of "fathers" and "sons" within Georgian gentry "society," the textual dialogic relationship creates horizontal linguistic kinship between educated Georgians and uneducated mountaineers as "brothers" (VII). This dialogue of intelligentsia and people is paired with and opposed to the dialogue with the drunken officer, who represents the Russian state and Russian civilization, and who claims to be a writer, an emissary from the world of Russian letters, and a notable inventor-in other words, an agent of civilizational progress. While the dialogue with the Georgian people associates high concepts of authentic Georgian traditions with the low forms of folk dialect, this dialogue instead reveals Russian civilization to be a farcical rendition of its European model, high concepts that are glossed with vulgar referents.

In all these dialogues, Chavchavadze's mediating position as intelligent is constructed as the almost invisible authorizing viewpoint that unites these dialogues into a single text, just as an intelligent is "entitled to speak for the good of the social whole" (Burbank 1996, 101). Serving both as a letter of introduction and a challenge to Georgian "society," it at once reproduces the pragmatic presuppositions of that discourse even as it seeks to transform them. All of these dialogues, in other words, build up a complex whole, an authorizing intelligentsia mythology, in which Chavchavadze underwrites his ability as intelligent to "speak for the people against the state" to an audience of other Georgian intelligenty.

The dialogue with Georgian Romanticism, in particular the figure of Grigol Orbeliani (1804-1883), a noted Georgian Romantic poet, noble and high-ranking tsarist official of the previous generation, is mostly overt. Chavchavadze achieves it through a series of pointed citations and barbed comments, but also by adopting the time and location (eve- 
ning at Mount Kazbek) of Orbeliani's "Night of Farewell" for a series of allegorical ruminations on nature that occupy Chavchavadze in the middle of his text (IV-V). The intertextual dialogue with Russian Romanticism is by and large achieved covertly, by means of formal imitation. ${ }^{8}$ Chavchavadze's title and genre recalls a much earlier account of the same journey by the Russian Romantic Aleksander Griboyedov (1795-1829), whose own "Travel Notes" about the same journey was composed in 1818 as a set of jottings and travel notes not intended for publication, but finally was published only a few years before in 1859, making it oddly contemporary (though whether the parallelisms between the texts reflect Chavchavadze's awareness of this text, or simply reflect the way the journey itself is divided into stages punctuated by postal stations, cannot be determined conclusively). Whereas Griboyedov, like many after him, is writing a private travel account of a journey from home into a strange, foreign land, Chavchavadze inverts the expectations produced by the title and genre, casting himself in the ironic role of an estranged "traveler" seeking to rediscover his homeland. This work is divided into eight separate "passages," and thus Chavchavadze's later travelogue formally echoes the structure of Griboyedov's work. He also disposes the passages of his journey (roman numerals I-VIII on Figure 3) spatially as a skewed icon of the passages of Griboyedov's journey (arabic numbers 1-8 on Figure 3). I note in passing that the divisions of each text reflect the "stages" of a journey.

The literary filiation with Griboyedov, a contemporary of Pushkin, places Chavchavadze in a covert genealogy with Russian Romanticism, just as his overt citation of Orbeliani places him in a genealogical relation to Georgian Romanticism. But more significantly, Griboyedov himself married Nino Chavchavadze (a distant relation of Ilia Chavchavadze), daughter of the Georgian noble and Romantic poet Aleksandre Chavchavadze. In the small circle of Georgian gentry who made up Georgian "society," literary relations and kinship relations were inseparable; if Orbeliani was addressed overtly as Chavchavadze's consanguineal literary kin, then Griboyedov could be reckoned covertly as his literary kin by marriage. By means of these intertextual allusions, Chavchavadze constructs a literary filiation as a "son" to two groups of wayward Romantic "fathers"-Georgian (Orbeliani) and Russian (Griboyedov). The dialogue with Russian and Georgian Romantics is done primarily through intertextuality of the landscape itself, an aestheti- 
cized landscape which more than any other was fraught with the political categories of colonial imaginative geography that Chavchavadze wishes to engage and revise.

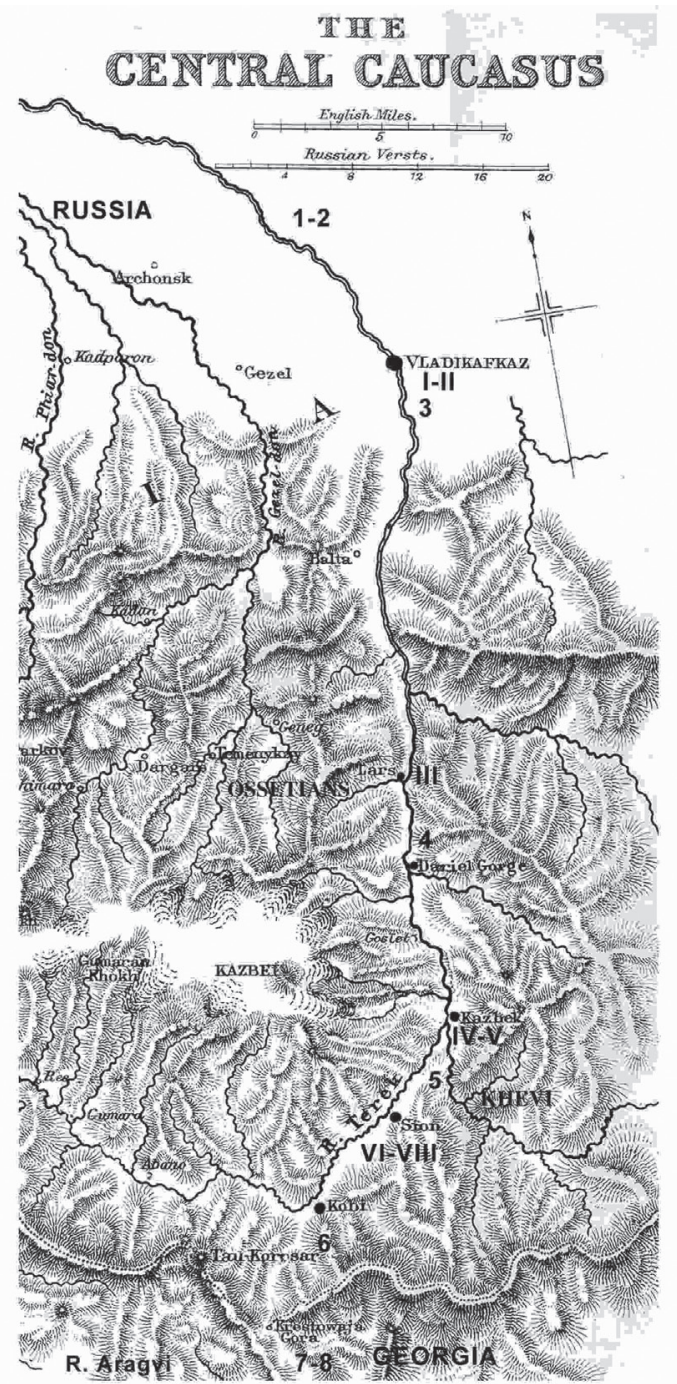

Figure 3

\section{Stages of Two Literary Crossings of the Dariel Pass}

I, II . . VIII: Stages (chapters) in Chavchavadze's Journey

$1,2, \ldots$ 8: Stages (chapters) in Griboyedov's Journey

(Adapted from map in Freshfield, 1869) 
An Aesopian Discourse of Nature: Talking Politics through Aesthetics Political engagement with Russian and Georgian Romantic imaginative geographies, which already reflected a strongly Orientalist essentializing mapping of geography to humanity (Layton 1992, 1994, 1997), occurred on the ground of aesthetics of the very natural landscape that Romanticism had invested with aesthetic or expressive value. Nature, then, assumes for Georgian discourse in this period a fundamentally political role. In an essentially "totemic" moment (Levi-Strauss 1963), expressive categories of aestheticized nature were mobilized as an Aesopian discourse of "talking politics." Perhaps this "Aesopian discourse," used in a tsarist literary context for veiled speech in the presence of the censor, was even more Aesopian than the ordinary Russian Aesopianism, for just as Aesop used tales of animals to speak in veiled terms of human society and politics, here the expressive categories of sublime nature, gloomy mountains, and raging rivers, are used totemically to produce an Aesopian language for political engagement with the inherited political-social-spatial imaginary of Romanticism. Russian and Georgian Romantics had ensured that aesthetics of the landscape, literary appropriations of nature, would be the point of departure for all further discourse about Georgia and the Caucasus. And nowhere was this imaginary found in such a concentrated and oft-described form as the passage to Georgia across the Dariel in the Caucasus, which was frequently compared to crossing of the Alps into Italy for the Grand Tour (Freshfield 1896, 87; on the Grand Tour which is the European object of comparison for the Dariel Crossing, see Chard 1999).

The crossing of watersheds is a transition from the uncivilized Caucasus to civilized, but Oriental, Georgia. In Russian Romantic Orientalist discourse, these two locales exhibit very different forms of alterity and suggesting very different colonial projects. As Layton $(1992,1994)$ argues, Georgia, though "civilized" and "Christian" was constructed by Russian Orientalism as a languid Oriental female, indeed, Georgia forms a classical Oriental counterpart to European Russia. ${ }^{9}$ By contrast, the Caucasus was the exemplary locus of masculinity, full of masculine tribesmen to be fought and emulated, and not a few lovely mountaineer maids widely rumored "to be very well disposed toward travelers" (Pushkin [1835], 139; more generally see Layton 1994, 1997).

The two places, the Caucasus and Georgia are also opposed by being associated very different aesthetic categories, the masculine aesthetics 
of the sublime and the feminine aesthetics of the beautiful. Russian Romanticism adopted and adapted the European aesthetic opposition between the sublime and the beautiful as part of an imperial geopoetic strategy to appropriate these regions and realize their own coevality with Europeans (Layton 1994, Ram 2003). In Pan-European aesthetic discourse, the qualities diagnostic of the sublime, emphasizing grandeur, vastness, "wild, barren, savage and 'frowning' landscapes" are opposed to the qualities of beauty emphasizing "cultivated, fertile, gentle, and 'smiling' landscapes" (Chard 1999, 110). These aestheticized and expressive spatial qualities are in turn aligned with gendered qualities of person, "the sublime with the masculine and the beautiful with the feminine" (Chard 1999, 117-18). Thus, Russian Romantics like Pushkin and Griboyedov saw the masculine sublime primarily in the gloomy crags and defiles of the Caucasus Mountains (home of fierce, warlike people like the Chechens), opposed to the feminized, Orientalized aesthetics of the beautiful that typified the Georgian plains (Layton 1992).

Georgian Romantics, in turn, adopted the Russian aesthetics of the sublime and the beautiful to establish their own coevality with their Russian peers in the appropriation of this same terrain (Ram and Shatirishvili 2004, Manning 2008). With the generation of the 1860s, Chavchavadze in turn adopts this same aestheticized discourse of nature to create an Aesopian political engagement with both these groups of forebears, but radically revises and reverses the aesthetics of the landscape. By eliminating the opposition between "beautiful" feminine Georgia and the "sublime" masculine Caucasus, he erases this distinction and identifies Georgia with the masculine sublime by laying claim to the roar of the Terek and the landscape of Dariel, paving the way for a Georgian ethnographic and literary "turn to the mountains" in the 1880s (on which, see Le Galcher Baron 1993, Manning 2007, 2008).

\section{Domesticating the Voice of the Terek}

If earlier Georgian Romantics exulted over the natural beauty of the Caucasus, it was as often as not a nature alien to humanity and devoid of human voices. For example, Aleksandre Chavchavadze (1786-1846), whose poem "The Caucasus" (published in 1852), while strongly indebted to Russian Romantic antecedents (see Ram and Shatirishvili 2004 for an extended treatment), nevertheless differs from them pointedly in factor- 
ing out all references to the human order often found in Russian renderings of the same landscape (the same tendency is true of Chavchavadze's proximal interlocutor, Grigol Orbeliani):

Absent in Ch'avch'avadze are any references to the human inhabitants of the Northern Caucasus: we find deer and goats, but none of the evocations of fierce Circassians and Chechens that abound in the poems of Zhukovskii, Pushkin, and Lermontov. In the absence of ethnographic detail the Caucasus appears through most of Ch'avch'avadze's poem as a hypostasis of nature, both a part of the created world and the theurgic force behind its creation. Whether apocalyptic or occasionally pastoral, the Caucasus are decidedly not human. (Ram and Shatirishvili 2004, 11)

It is very much as if Georgian Romantics had fully internalized Russian Romanticism's aesthetic appreciation for the landscape, but somehow balked at finding anything similar to appreciate in the people living there.

Ilia Chavchavadze, in a sense reversing this tendency of earlier Georgian (but not Russian) Romanticism, humanizes this natural order (giving a human voice to the roar of the Terek) as a prologue to naturalizing the human order (by naturalizing the human voice of the Terek-dwelling peasant, Lelt Ghunia). In so doing, Chavchavadze radically revises the geopoetics characteristic of these earlier Romantics, which as often as not sought to align Georgia with Russia against the Caucasus, by creating a novel geopoetics in which the Caucasus, in the form of the Terek River, is identified with Georgia as opposed to Russia. In Griboyedov's text, the frightening animal roar of the Terek in the first five passages marks the terrain as being the uncivilized, dangerous, frightening Caucasus, a land of war, strife, and uncivilized mountaineer tribes and bandits (see in general, Layton 1994). The sixth passage marks the passage from the uncivilized and frightening Caucasus symbolized by the roar of the Terek to the pleasant and peaceful Georgia, symbolized by the Aragvi River, "the morning song of the Georgians." 10

Chavchavadze radically revises this imaginative geography by dispensing with the Aragvi (which flows from these mountains into the 
plains of Georgia) as a symbol of beautiful Georgia as opposed to the sublime Caucasus symbolized by the Terek. The Terek can now stand alone as a symbol of the Georgian Caucasus (the Xevi district beside the mouth waters of the Terek). By eliminating the ever-present inherited opposition between the Aragvi and the Terek-between the peaceful, feminine, civilized, and subdued Georgia and the warlike, masculine and free Caucasus - he brings Georgia into the Caucasus. ${ }^{11}$

Chavchavadze also proposes a radical rereading of the meaning of the roar of the Terek that figures in the texts of Orbeliani, Griboyedov, and others. The furious animal roar of the unbridled torrents of the Terek in the Caucasus is a long-standing Romantic symbol of mountaineer masculinity and freedom. The novelty of Chavchavadze's reading lies in how he appropriates the rebellious freedom of the Terek as part of the Georgian national tradition, representing an authentic Georgian culture which can be favorably compared to the pretended civilization of Russian rule, represented by the subdued flow of the Terek in the plains of Russia: "Happy Terek! You are at your best when you are restless. Stand still but a little while and do you not turn into a stinking pool and does not this fearsome roar of yours change to the croaking of frogs!" (IV)

The Terek is identified with freedom of motion and change, but not necessarily modernity or progress, for Chavchavadze's program cannot easily be understood as a progressive one. Rather, it is a somewhat jarringly eclectic combination: a celebration of mountaineer freedom and apologetic for the harmonious and mutually beneficial relations between estates that once-it is claimed-characterized Georgian feudalism. The motion and roar of the Terek in the mountains represents political self-determination and freedom of the (now defunct) autonomous community-based institutions of the mountaineer polity (eroba, what is more usually called the temoba by indigenous Moxevian writers like Aleksandre Qazbegi [1880, 164, 2]). But at the same time as he mourns the demise of the eroba, Lelt Ghunia extols the recognition of reciprocal obligations of service and reward and general harmonious relations between estates that once apparently existed between Georgian peasants and nobles. All this was lost, according to Lelt Ghunia, under the "empty peace" of the Pax Russica, which places the people economically at the mercy of usurious Armenian merchants and abrogates the system of reciprocal service and rewards between estates that once apparently made the Georgian people valorous. This changed social state of affairs, 
brought by the subjection of the Georgian people to Russian rule and cooptation of Georgian nobles like Orbeliani into Russian service, is again likened to the change of the natural order, witnessed in the domestication of the animal fury of the Terek as it moves into Russia. Chavchavadze notes that at Vladikavkaz, in the plains, the Terek flows "as placid, as silent, as if it dwelt under the rod or had received a high official post (chini)" (II); or as Lelt Ghunia would have it, the stagnant water of empty peace brought by Russia is for servile frogs, but free trout splash happily in the torrential Terek (VII).

The prior Georgian and Russian Romantic descriptions of this landscape with which Chavchavdze engages explicitly are notable for their rapturous communion with sublime nature (and Chavchavadze's is no exception), but in them, the noisy natural order (the terrifying wild animal roar of the Terek) is sometimes complemented by the complete silence of cultural order (mountaineer "Terek-drinkers"). In the poetry of Georgian Romantics like Aleksandre Chavchavadze or Grigol Oribeliani, if local inhabitants appear, they are largely of a piece with the natural order. For the Russian Romantic Griboyedov, the central and defining feature of the landscape is the inhuman "noise of the Terek." For Ilia Chavchavadze, by contrast, the phusiomorphic noise of the Terek by slow degrees is anthropomorphized into an articulate plaintive human voice which is ultimately identified with the fully human voice of the Terekdrinker, Lelt Ghunia. ${ }^{12}$

Chavchavadze humanizes the natural order via a subjective revelation that organizes the text, one which is mirrored in the natural order in the changes in the flow of the Terek as he ascends from Russian plains to Caucasian mountains. At first, a reluctant Terg-daleuli in the plains at Vladikavkaz, where the Terek flows lifeless and silent, he refuses to even look at, let alone drink from, the Terek, lest someone think him a Terg-daleuli (II). Ascending into the mountains, the Terek, ever more torrential, ever noisier, enters into communion with nature, finally coming to feel "a secret bond-a concord-between my thoughts and Terek's complaint" (V). Chavchavadze transforms the inchoate noise of the Terek into a human voice; first, the anthropomorphized voice of the river, whose complaint, the complaint of his motherland, he comes to understand $(\mathrm{V})$; and then in the very real voice of the Georgian mountaineer who dwells by the Terek, whose dialect-inflected voice Chavchavadze appropriates for his political message (VI-VII). The furious roar 
of the Terek in the mountains now appears explicitly as the voice of the free Caucasian mountaineers, who are, it needs to be added, also specifically Georgian mountaineers. Having humanized the voice of nature, the Terek, he now turns to naturalizing his relationship to the cultural order, giving voice to the Terek-dweller.

\section{Form and Content: Languages of Culture and Civilization}

This revisionist geopoetics of the natural order is paralleled on the linguistic plane in two lengthy dialogues which Chavchavadze has en route with representatives of the Russian state in the form of a drunken officer (III) and of the Georgian people in the form of Lelt Ghunia (VI-VII), a Georgian mountaineer peasant. The viability of a geopoetics that assimilates Georgia into Russia (characteristic of the older generation of Georgian Romantics) is called into question when the Russian officer reclassifies Chavchavadze from enlightened interlocutor to benighted local when he finds out Chavchavadze is actually a Georgian. At the same time, the parallel inherited geopoetic opposition between Caucasus and Georgia is elided when the mountaineer Lelt Ghunia and plains-dwelling Chavchavadze discover their common essential Georgianness underlying their accidental differences of dress and dialect.

Further developing this revisionist geopoetics, Chavchavadze uses the opposition between form and content in these two dialogues to show that Russian civilization is a form with at best debased content, while the traditional culture of the mountaineers, though expounded in the rather homely garb of folk dialect, is revealed to be authentic. He thus reverses the apparent value of form and content.

Chavchavadze continually defines and glosses terms to draw our attention to the opposition of form and content, but he works these devices differently in each dialogue, with different degrees of explicitness of framing (Bauman 2004) and with important rhetorical effects. The dialogue with Ghunia relies on implicit operations of glossing that allows recognition of natural similarities within the heteroglossia of dialect, and, moreover, recognition of Chavchavadze's kinship with Ghunia as Georgians. The linguistic relation is a fraternal kinship relation, therefore Chavchavadze is truly an "organic" intellectual. Using dialectal differences as a basis for the recognition of natural similarities, meanwhile, rhetorically resolves Chavchavadze's anxieties about whether Chavcha- 
vadze will understand his country's voice, the voice of Ghunia.

But what shall I do if my country tells me her complaint, the secret causes of her sorrow, her hopes and despairs, and I, unaccustomed to her language, cannot understand her language, her speech? (III)

But just as quickly, he concludes that there exists a natural kinship connection between himself as patriot (mamulishvili lit. "child of the fatherland") and the fatherland (mamuli) itself, which would allow him both to understand the complaint of his fatherland and to make himself understood in turn:

I decided that my country would receive me and acknowledge me because I am its blood and its flesh; I should understand its words and speech because a patriot [mamulishvili] hearkens to his fatherland [mamuli] not only with his ears, but with his heart too, which understands even the unspoken words; I will make them hearken to my words too, for a parent always listens to the words of his child. (III)

The dialogue with the Russian officer, by contrast, works with radical disjunctures between forms and meanings that are mediated only by his own explicit fiat, by which he seeks to make the difficulty of "scientific discourse" understandable to the unenlightened local, Chavchavadze. Again the problem is one of failure of recognition. When first he learns that Chavchavadze hails from St. Petersburg, he is full of great respect for an enlightened visitor from the pinnacle of civilization in these benighted parts. Upon learning that Chavchavadze is a local, "that is, a Georgian or an Armenian" (III), he imputes a radically opposed identity to him; he becomes full of contempt, and is merely glad that at least Chavchavadze is a Georgian and not a despised Armenian (a topic on which both he, Chavchavadze and Ghunia apparently all agree). Because it is revealed that Chavchavadze is essentially a benighted (Oriental) local and only accidentally resembles a (Western) visitor from a center of enlightenment, the Russian officer now assumes the role of an enlightener whose task is to explain and gloss the complex terminology of civilization for 
the backward Chavchavadze. Hence, where the first dialogue involves implicit recognition of essential identity underlying apparent difference of outward form, the second dialogue, premised on misrecognition of essential underlying difference despite appearances, involves explicit glossing operations that inadvertently reveal the obscurantism of the civilizing pretenses of the Russian state.

At issue are two very different views of form and content in language. One is a view of language, characteristic of Enlightenment thought (Taylor 1975, 14), where signs and their objects, form and content, are externally related (in that both sign and signified exist autonomously of the sign relation, and are therefore brought together arbitrarily by stipulative fiat), parodied by a reductio ad absurdum in the Russian officer's civilizing discourse (where French words are arbitrarily made to stand for discordant Russian realities). The other (characteristic of post-Enlightenment thought) is one where signifier and signified, form and content, are internally related, mutually constituting, organically interdependent, unable to exist apart. Here language is not merely an arbitrarily chosen means of reference about independently existing, objective states-of-affairs, but also expressive of, and therefore constitutive of interior, subjective essences (here, Georgianness). Such an "expressivist" view of language is essential, as Taylor points out, to any nationalism grounded in language (Taylor 1989, 415), and is certainly central to the discussion of the relation of form and content in Chavchavadze's dialogue with Lelt Ghunia. Hence, the two dialogues enact in their implied theories of language Enlightenment discourses of "civilization" as opposed to post-Enlightenment discourses of authentic indigenous "culture." Just as Chavchavadze brings himself into an organic relation with Lelt Ghunia on the basis of an expressive view of language and authentic culture, he pries Russia apart from European civilization by the arbitrariness and obscurantism by which Francophone civilizing discourses are accommodated to Russian realia, leaving Russia in a noman's land between culture and civilization. In this process, he appears to revalorize the received term Terg-daleuli itself, from a term meaning "one who has received (false) enlightenment in Russia by crossing the Terek" to one meaning "one who has found (authentic) culture among the Georgians who dwell by the Terek." 


\section{Describing Dialect}

Nowhere is the new concern for authenticity of representation of folk language more clear than in the dialogue with Lelt Ghunia (VI-VII), which resembles a folkloric text embedded within a larger prose narrative. The dialogue is a striking exercise in attempted literary realism: not merely a sprinkling of dialectics for flavor, it is possibly the first systematic, if distorted, representation of a nonstandard dialect of Georgian. ${ }^{13}$ Lelt Ghunia's dialect is rendered in such a way that both its specificities of form are highlighted, but also its essential Georgianness is at the very same time retained. Dialectal difference within language is revealed to be a kind of accidental difference within a framework of essential similarity, differences of form of what are in effect the same words, so too differences of dialect of what are the same language. So too, the differences between the Moxevian peasant mountaineer Lelt Ghunia and the plains-dwelling gentry Chavchavadze become matters of outward form of dialect or dress that obscure an inner identity of Georgianness.

Chavchavadze begins their first dialogue (VI) by a number of failed gambits that make him resemble a Georgian noble of the previous generation, failing to recognize Ghunia's Georgianness underneath his mountaineer garb, failing to recognize the human poverty writ large in the entrancing natural beauty of the mountains. The remainder of the dialogue in VI allows Ghunia to correct these misapprehensions. In the following dialogues, the comparable terms of Chavchavadze and Ghunia's dialect are emphasized in brackets.

'Where [sadauri] do you come from?'

'Where [sadável]? From Gaibotani, here in the mountains on the banks of the Terek.'

'Are you Georgian or Ossetian [osi]?'

'Why would I be an Ossetian [ovsí]? I am a Georgian, a Moxevian.'

'Your home is in a good place.'

'It's not so bad [gonjái].* It suits our poverty.'

'Water and air like this are happiness itself.'

'Hm!' laughed the Moxevian.

'What are you laughing at [icini]?'

'I laugh [vicini] at the laughable. An empty stomach cannot be filled with those.' 
*Gonjai-cudi [gonjai -“bad"] (VI)

If the first dialogue concerns Chavchavadze's misrecognition of Ghunia as a possible non-Georgian mountaineer (an Ossetian), the second dialogue (VII) involves Ghunia's misrecognition of Chavchavadze as a Russian, as if echoing Chavchavadze's concern, that, as "one transplanted and reared in another soil" (III), he would not recognize his country, and his country would not recognize him.

The substance of the dialogue deals with the defunct ethnographic institutions of the Moxevians and the debasing effect of Russian political domination and Armenian economic domination on the Georgian people, both in the narrow sense (the eroba "(village) community," the traditional form of autonomous mountaineer polity) as well as broader sense (the Georgian eri "nation, folk, people"). ${ }^{14}$ As Ghunia explains the traditional ethnographic functions of an old monastery dedicated to the Holy Trinity to Chavchavadze, Chavchavadze demands clarification about one of them, the people's council (erta sabch'o), an important institution of the eroba (here translated "community"), at which point it is revealed that the institutions of the eroba no longer functions under Russian rule: ${ }^{15}$

'What in the world is a council [sabch'o]?'

'A council [sabch'oi]? There is a cell there, where justice was dispensed by judges. Whenever any serious affair arose in Xevi it was judged there. . . When there took place in the community a great pursuit, any important affair, a big election, the community went there, chose as judges wise old men, men famed for their wisdom [p'eit'róbit]*, set them up in that cell to judge. Whatever these mediators then, in the name of the Trinity, having asked grace from God, speak and decide, none breaks, none infringes.'

'Have you been present at such a tribunal?'

'How should I have been present? I am telling you tales of former days.'

'Why is it now [exla] no longer as it was?' 
'Nowadays [ac'ina]? ... Where is the community [eró$b a]$ ? We are under Russia. Now everything is destroyed, everything is changed.' (VII) ${ }^{16}$

*p'eit'robit-met'is gonebit saxelgantkmulni (p'eit'robit"famed for great wisdom")

In both these dialogues, Chavchavadze uses the mechanisms of dialogue itself, specifically questions, answers, and repetitions to establish that differences of form overlay identities of content, an "outer clothing" of different dialect forms of what are essentially the same words. Using these devices, the translational equivalence of partially different dialectal word forms as "different ways of saying the same thing" is established implicitly in conversational question-and-answer pairs.

As can be seen from the examples above, Chavchavadze's questions are frequently met by a two-part reply from Ghunia. First, Ghunia repeats a single word from Chavchavadze's question as a question; for example, Chavchavadze: sadauri? ("where from?"), Ghunia: sadável? Chavchavadze: osi? ("Ossetian?"), Ghunia: ovsi? Chavchavadze: sabch'o? ("council?") Ghunia: sabch'ói? Chavchavadze: exla? ("now?") Ghunia: ac'ina? ("nowadays?"). This foregrounds the sundry differences of dialectal form (such as the pervasive marking of accentuation, for example) between otherwise equivalent words, as if striving to ascertain whether Ghunia's words sadável or sabch'ó "mean the same thing" (or "are the same words") as Chavchavadze's words sadauri or sabch'o. Then, Ghunia answers Chavchavadze's question in terms of its content, explaining where he is from or what a sabch'o is. The organization of the dialogue itself recursively divides off dialect form (the echo question) from content (the answer). At the same time, the first part of the response foregrounds differences of dialect form and acts as an implicit glossing operation establishing the underlying equivalences of words.

Whereas this device allows the common Georgianness of words to be recognized despite differences of "dialect," Chavchavadze establishes equivalence of meaning between different words through a separate textual device, the philological footnote. The text has six philological footnotes that offer glosses of Moxevian vocabulary (for example gonjái "bad" in the dialogue above glossed as standard Georgian cudi "bad"). These glosses are often presented denuded of other Moxevian formal pe- 
culiarities such as pervasive marking of accentuation, and thus as if they are part of the standard Georgian vocabulary. Thus there are two stages of "translation" of dialect into standard: a translation of form, by which an unfamiliar word in the text (e.g., t'alávar) is glossed in the footnote in a "citation form" denuded of distinctive dialectal features (e.g., t'alavari). This is followed by a translation of content, where this word is glossed by a standard Georgian word (t'anisamosi "clothing"). Thus, while the dialogic system discussed above uses the same words to present different dialect forms, this system highlights the essential identity of words across dialects, backgrounding accidental differences of dialectal form. The footnotes present Ghunia as if he were himself an ethnographic or philological text engaged in dialogue with his transcriber. If the dialogic glossing discussed above produces a precarious equality between their utterances and themselves as speakers of Georgian, the footnoting device reestablishes Ghunia as a philological text (speaking a nonstandard dialect) and Chavchavadze as a philologist (speaking the standard dialect).

As "dialect" is the outer garb of words, so too do their different styles of dress prevent Chavchavadze and Ghunia from recognizing their common Georgianness. On their first meeting, Chavchavadze mistakes Ghunia for an Ossetian, for which he receives a testy rebuke (VI). ${ }^{17}$ In turn, before he reveals his true opinion of Russian civilization, the peasant Ghunia wants to know Chavchavadze's mileti (derived from the Ottoman term of ethno-religious classification, millet), assuming from his dress that he is a Russian (VII). "I am a Georgian, can't you recognize me?" is Chavchavadze's surprised response. "How would anyone recognize you?" Ghunia replies, "You don't dress like a Georgian. You resemble a Russian." Attempting to find a basis for mutual recognition that does not depend on such outward forms, Chavchavadze makes special pleading that Georgianness is not a matter of outward alienable form (dress), but a more essential trait, represented perhaps by language. Ghunia objects that "many speak the Georgian language, Armenians, Ossetians, Tatars, other millets" (VII). Chavchavadze concludes that perhaps Georgianness is not a matter of such relatively outward forms (dress, language), but still more inner essence, a matter "of the heart." Ghunia dubiously agrees, noting merely that clothing, at least, has the advantage of being visible. "Who can see into the heart?" he complains. For Chavchavadze, Georgianness is an essential content whose recognizability is not impaired by variation in outward form of dress or even language (though 
perhaps it should be reflected or expressed in it). Ghunia, in turn, argues that the outer form (dress) must express the inner content, or the outer form becomes the inner reality. "In Russian dress, a Georgian becomes a foreigner" (VII), just as the Terek changes its nature as it moves from Caucasian mountains to Russian plains (II).

\section{Defining "Civilization"}

The form of Lelt Ghunia's speech is as humble as that of the Russian officer's is "scientific" and elevated. But in terms of content, the reverse is the case. The historical predicament of Georgia is that the authentic culture of the folk has been displaced historically by the empty forms that Russian civilization has brought with it. Form and content are divorced in reality as well as discourse, a chiasmus of high terminology and vulgar referents of the Russian officer's speech is mirrored in the realities of Russian civilization.

The Russian officer is not the only representative of a civilized Europe in this text. In fact, Chavchavadze's first conversation at Vladikavkaz is with a French traveler, who, mocking the notorious Russian postal carts, appears merely to authoritatively demonstrate that Russians are not Europeans. "The whole of Russia travels like that? ... Who in the world will ever catch up with them?" is his snide observation (I). This rhetorical separation of backward Russia from civilized Europe is continued in the speech of the drunken Russian officer (III). This dialogue has the quality of a "Through the Looking Glass" exposition of Russia's civilizing mission, presided over by a Russian analog of Humpty Dumpty, who glosses over the gap between form and content by fiat. The officer condescendingly notes that Chavchavadze, like most locals ("that is, Georgians or Armenians"), owing to his lack of enlightenment, does "not understand logical, orderly reasoning" and probably does not even know the meaning of terms like civilizacia, associacia, arghumentacia, inteligencia, kassacia, and pilologia (III). Since, of course, it is soon revealed that the officer himself does not know what these terms mean, it can be concluded that he chose them on the basis of their purely formal properties, that is, because they sound French and rhyme. Russian civilization is presented as an empty form, a Francophone jargon consisting of words that rhyme with civilizacia.

The scientific officer also engages in an explicit discourse of defini- 
tional glossing, which seeks to bridge the imputed gap between his position as civilizing Russian and Chavchavadze's position as uncivilized local, conceived as a linguistic barrier between "scientific language" and "vulgar language," bridged by acts of "translation" that debase the meanings of words. This glossing of "scientific" terminology (mostly of European derivation) by "low" referents reveals the scientific officers own lack of enlightenment, trading in high-minded abstractions for low-minded vulgarities, revealing once again Russia's claims to civilization as being a fundamental vulgarization of the real thing, the empty form of civilization as opposed to its reality. For the drunken Russian officer, the pinnacle of civilization is Izler's Garden in St. Petersburg, notable for its "fairies," a scientific term he is certain Chavchavadze will not understand:

'Do you know what fairies are? That is a scientific word, perhaps you don't understand. If we translate it into the vulgar tongue that means that the garden is full of merry-eyed damsels. If you like you can take one by the arm, and, if you like, a second. See what enlightenment can do. Your women-as soon as they even see a manthey hide.' (III)

The scientific officer continues to help Chavchavadze understand scientific discourse by this process of glossing, of translating scientific language into the vulgar tongue: "It will be difficult for you to understand scientific conversation, but I will translate scientific words here and there into simple language and so thus make scientific conversation easy for you" (III). He then proceeds, step by step, and numerous false starts, tautologies, and asides, to gloss "enlightenment" for the unenlightened Chavchavadze. In his asides, he inadvertently identifies the Russian imperial metropoles of Moscow and Petersburg with the colonial outposts of Stavropol and Vladikavkaz, that is, cities not larger than Chavchavadze's own unenlightened Tbilisi, thereby undermining his assertions of the self-evident superiority of metropole over colony. Let us follow the culmination of his explanation:

'Now when we begin by saying that your country is not enlightened we must also say what enlightenment is. I 
will explain this by an example; imagine a dark roomhave you imagined it or not?'

'I have imagined it.'

'No, perhaps you have left a window open somewhere, close it too.'

'I have closed it', I said, and smiled.

'Very good. When you fasten the window you must let down the blind.'

'I have let it down.'

'When you have let down the blind the room is darkened, you can see nothing. Suddenly a candle is brought and the room is illuminated. That is enlightenment. But really, I tell you this cigarette is not bad. Is it from Petersburg?'

'No, I bought them in Vladikavkaz.'

'It's all the same. Now do you understand the meaning of enlightenment?' (III)

Having defined enlightenment, the officer turns to measuring its progress among the locals. "How does civilization go among you?" the officer asks. Just as the unit of measurement of enlightenment turns out to be lumens for the Russian officer, the dry measure of civilization turns out to be "generals." By "civilization" therefore, the scientific officer wishes to know how many Georgian generals there are. ${ }^{18}$ When Chavchavadze answers "about twenty," the officer exclaims with disbelief, "This is great civilization!" After considerable clarification of the "scientific" definition of "general" (a matter ultimately having to do with mustaches and epaulettes), he quickly determines the mathematical constant for the rate of growth of civilization in Georgia, measured as a constant in generals per year: twenty Georgian generals, seventy years since Georgia has become a Russian colony, yielding a constant rate of two generals every seven years.

As the conversation becomes increasingly deranged, the officer reveals an invention of his own devising that will give value to ordinary flies (yes, flies), which will replace the complex and expensive machines that are the engines of progress in European countries like France. As a result of his invention, he cheerfully anticipates the beginnings of a bustling commerce in flies, with the result that soon there will be "fly shops" all across the empire. Such inventions in the aggregate, products of en- 
lightened minds, which give value to worthless things, will lead to the establishment, perhaps, of an Izler's garden, symbol of enlightenment, in Chavchavadze's own backward town of Tbilisi, leading the elusive and standoffish women of Georgia to promenade boldly. Hence, Tbilisi will be transformed into a kind of paradise, the last term he tries to define for the unenlightened Chavchavadze: "Then the people will see their paradise, as the learned say, that is to put it simply . . . but what shall I say, paradise in the vulgar tongue is also paradise." (III)

\section{Conclusion}

Chavchavadze represents the core of the Russian civilizing discourse as a set of acts of translation and definition by which the officer attempts to mediate the putative divide between himself as enlightener and Chavchavadze as unenlightened local. The dialogue is the opposite of the dialogue with Ghunia. It is a parodic lampoon of the empty pretenses of the colonizing Russian state to a civilizing mission, confronted with a "realistic" ethnographic account of the predicament of the peasantry. The two dialogues, belonging to primary genres of parody and critical realism respectively, are juxtaposed without authorial comment. The processes of glossing found in each dialogue differ in degrees of explicitness of framing, the dialogue with Ghunia leading to implicit recognition of kinship of Georgians, the dialogue with the Russian a divorce of form and content sutured together by explicit fiat. The dialogue with Ghunia reveals lowly folk dialect to be a vehicle capable of bearing authentic culture, while the dialogue with the officer reveals the "scientific" Francophone language of the civilizer to be the empty jargon of a spurious civilization. ${ }^{19}$

By these various formal means, Chavchavadze constructs a complex genealogy for himself as intelligent, establishing an overt literary genealogy that addresses his text as a son's reply to a wayward generation of Georgian fathers who have abandoned the Georgian people for the Russian state (Orbeliani), and at the same time a covert sideward glance is made to the affinal relations of these same Georgians among Russian Romantics (Griboyedov). Distancing himself by opposing his kin within the literary community of Russified Georgian society, Chavchavadze turns to the people, establishing a naturalized fraternal kinship based on shared language within the speech community of Georgians (Lelt Ghunia), which he can use as a foil for the empty claims of the Francophone 
universe of discourse of Russian civilization represented by the Russian state. At the same time, he revalorizes the term by which his own generation of intelligentsia were already known, terg-daleuli, from a term which implies a Russophile geopoetics of assimilation of Georgia to Russia via enlightenment, to one which instead seeks to find authentic culture among the Terek-dwelling mountaineers of the Georgian Caucasus.

Chavchavadze's Letters of a Traveler is in many ways a watershed moment between the "Romanticism" of earlier generations and the "realism" of following ones. The "Romantic" allegorization of nature in this work transforms the landscape into a series of intertexts through which Chavchavadze can engage polemically with an entire series of Romantic predecessors, just as the "realist" transcription of the human voice of Lelt Ghunia makes this text the beginning of another intertextual series for Georgian intelligentsia to write about Georgia. Russian Romanticism had transformed the Dariel crossing into an intertextual space in which Russians could constitute themselves as Europeans (Greenleaf 1991, 1994). Georgian Romantics, in turn, by redescribing their own landscape in these borrowed European-Russian categories, established their own coevality with their Russian peers (Ram and Shatirishvili 2004, Manning 2008). Chavchavadze's appropriation of this Romantic discourse allows him to contest all the major themes and presuppositions of the Russian and Georgian Romantic imaginary of the Caucasus. In turn, Chavchavadze's Letters of a Traveler would spawn its own Georgian progeny. In the 1870s, his Aesopian discourse of nature (indebted to Romanticism), figured by the zoomorphic or theriomorphic, and then anthropomorphic Terek, and his realistic transcription of the voice of the Terek-drinker Lelt Ghunia on the northern boundaries of Georgia would provide a set of intertexts that could be transferred to the southern boundaries of Georgia, allowing correspondents like $S$. Bavreli a discursive framework for an internal Orientalist project of exploring the newly reconquered lands of "Ottoman Georgia." After the failure of this intelligentsia project of a rapprochement with the estranged "brothers" of Ottoman Georgia in the early 1880s, Chavchavadze's thematic focus on the mountaineers of Georgia as a privileged locality for pristine Georgianness of speech and custom would bring a harvest in the immense explosion of realist ethnographic and folkloric literature dealing with these regions Georgian press of the 1880s, beginning with the ethnographic and literary writings of the Moxevian writer Aleksandre Qazbegi. ${ }^{20}$ While Bavreli's writings continue the 
hybrid aesthetics of Chavchavadze, continuing both the Romantic "Aesopian" discourse of nature (in the form of anthropomorphic rivers and "expressive" landscape) and the "realist" transcription of the voices of its people, the writings of later realists would firmly distinguish between the natural (material) and human orders, "life" would become exclusively a property of the people, and a realist description of "life" would turn resolutely away from even a fictional aesthetic anthropomorphism of nature. While the bulk of this book will explore the former moment, the internal Orientalist project of knowing the strange lands of first Western Georgia (in the 1860s-1870s) and then Ottoman Georgia (in the 1870s), we will skip ahead a moment in the narration to glance at the beginnings of this second discourse of "our mountaineers," a discourse which begins, once again, with a revisionist reading of the Dariel crossing. 